\title{
A in(efetividade) do Direito Penal na legislação ambiental no Estado da Paraíba
}

\section{Marcos Aversari}

Universidade Federal da Paraíba. Programa de Pos-Graduação em Desenvolvimento e Meio Ambiente. Centro de Ciências Exatas e da Natureza. João Pessoa-PB (CEP 58051-900) E-mail: marcosaversari@yahoo.com.br

Resumo. A Constituição Federativa do Brasil de 1988 estabeleceu que o meio ambiente é um bem de uso comum do povo, assegurando a todos o direito de tê-lo equilibrado, impondo ao Poder Público e à coletividade o dever de defendê-lo e preservá-lo à presente e às futuras gerações e ampliou as ações judiciais na tutela ambiental. Partindo desse preceito constitucional, a legislação ambiental brasileira tornou-se uma das mais completas e vastas do mundo, sendo composta por numerosas leis, das quais a Lei $n^{\circ}$ 9.605/1998 (Lei dos Crimes Ambientais), que representa um marco importante no Direito Penal brasileiro, garantindo à sociedade, aos órgãos ambientais e ao Ministério Público a agilidade e a eficácia para punir as pessoas físicas ou jurídicas que cometerem qualquer infração contra o meio ambiente. Com o objetivo de verificar a efetividade da aplicação desta Lei, analisou-se a quantidade de auto de infração lavrados pelo Instituto Brasileiro do Meio Ambiente e dos Recursos Naturais Renováveis (IBAMA) e pela Superintendência de Administração do Meio Ambiente (SUDEMA), no período de 2007 a 2011. Neste período, foram aplicados por estes órgãos um total de 4.957 autos de infração por desrespeito às normas ambientais. Podemos concluir que, apesar da Lei dos Crimes Ambientais (Lei ${ }^{\circ}$ 9.605/1998) ter punições severas para as infrações cometidas contra o meio ambiente, o número de autos de infração, lavrados na SUDEMA e no IBAMA foram numerosos, devido à falsa impressão de impunidade, provocada pela ineficiência do Estado em cobrar as multas aplicadas e do judiciário considerar estas infrações penais como de menor potencial ofensivo.

Palavras-chave: Direito ambiental, Crime ambiental, Proteção ao ambiente, Responsabilidade ética.

Abstract. Effectiveness and efficiency of criminal law in environmental legislation in the Paraiba State. The Constitution of Brazil of 1988 established that environment is an asset of common use, ensuring all the right to a balanced environment, imposing upon the state and society the duty to defend and preserve it to this and future generations, and enlarged the lawsuits on environmental protections. From this constitutional provision, the Brazilian environmental legislation has become one of the most complete and extensive in the world, consisting of numerous laws, which the Law no. 9,605/1998 (Environmental Crimes Law), which represents an important milestone in Criminal Law Brazilian, ensuring the society, environmental agencies and the public prosecutor's agility and effectiveness to punish individuals or legal entities who commit any ISSN 2359-1412/RBGAS-2015-0109/2/3/11/187
Recebido: 07/07/2015

Aceito: 15/12/2015

Publicado: 31/12/2015

Acesso Aberto Artigo completo

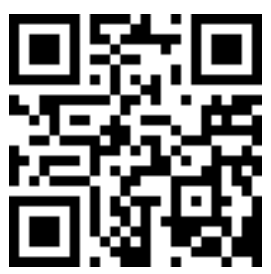


offense against the environment. In order to verify the effectiveness of application of this Law, we analyzed the amount of assessment notice issued by Brazilian Institute of Environment and Natural Resources (IBAMA) and Superintendency of Environmental Management (SUDEMA) in period 2007 to 2011. During this period, were applied by these agencies a total of 4,957 notices for failure to comply with environmental standards. We can conclude that, despite the Environmental Crimes Law (Law no. 9,605/1998) have severe punishments for offenses committed against the environment, the number of notices, and plowed by SUDEMA and IBAMA were numerous, due to false impression impunity, caused by the inefficiency of state in collecting the fines and court consider these criminal offenses of lower offensive potential.

Keywords: Environmental rights, Environmental crimes, Environment's protection, Ethical responsability.

\section{Introdução}

Desde o surgimento do homem no Planeta Terra em sua busca desenfreada pelo poder e crescimento destruindo e subjugando as espécies, o meio ambiente vem sofrendo sérias alterações, que atualmente está se tornando um dos grandes problemas para todos os seres que habitam a Terra. A degradação ambiental que deixa consequências muitas vezes irreversíveis no ar, na água, no solo, na fauna, na flora e para a sociedade humana é cada vez mais crescente no mundo atual.

Podemos observar um aumento muito rápido na erosão do solo, no desmatamento das florestas, na perda da biodiversidade, na destruição da camada de ozônio, no aquecimento global, na contaminação das águas, no desequilíbrio climático.

Tais atitudes fizeram despertar na consciência da humanidade o ideal de conservação do meio ambiente como uma questão de sobrevivência para a nossa espécie e as demais.

Esta tão brilhante conscientização fez com que a ciência que regula a vida de todo ser humano em sociedade, o Direito, não pudesse ficar alheio a tal situação.

E pela primeira vez na história das Constituições Brasileiras por estar, segundo Reale Júnior (2005), a questão ambiental extremamente madura e debatida, o meio ambiente foi elevado à categoria de bem jurídico constitucional. Assim na Constituição Federal de 1988, no art. 225 e seus parágrafos, surgem as primeiras medidas de controle de responsabilidade criminal ambiental para aqueles que atentem contra o meio ambiente (Brasil, 1988).

Após este ponto de partida começam o surgir novas leis que garantem a preservação do meio ambiente ecologicamente equilibrado. Dentre estas, a mais importante é a Lei ${ }^{\circ} 9.605 / 1998$, que é a Lei dos Crimes Ambientais (Brasil, 1998). Esta lei dispõe sobre as sanções penais e administrativas derivadas de condutas e atividades lesivas ao meio ambiente e da outras providências. O Direito Penal ganha mais uma nova atribuição a de punir aqueles que praticam crimes contra o meio ambiente.

Essa nova atribuição do Direito Penal, entretanto, tem apenas função simbólica. Pois não é possível, mesmo cientificamente, comprovar que sua vigência tem impedido $\mathrm{o}$ processo de degradação do meio ambiente em suas várias espécies. Hassemer (1998) afirma existir um "déficit de execução", que mostra a inconsistência da legislação penal ambiental gerada por dois fatores: as cifras negras que são casos que nem chegam ao conhecimento das autoridades públicas, ou seja, são infrações penais desconhecidas "oficialmente" que não são solucionadas ou punidas, e o outro fator é a seletividade dos condenados que na maioria das vezes pune apenas os pequenos cometedores de crimes contra o meio ambiente.

Os objetivos principais do presente trabalho foram: verificar se o Direito Penal vem sendo um instrumento eficaz de 
proteção ao meio ambiente; verificar o histórico da tutela ambiental na legislação brasileira; constatar através de bibliografia o que são crimes ambientais e a legislação penal ambiental; verificar na área estudada quantas infrações ambientais foram cometidas; analisar se a tutela penal é uma medida efetiva de proteção ao meio ambiente na área estudada; diagnosticar os principais motivos da ineficácia jurídica do direito penal na legislação ambiental da área estudada.

\section{Material e métodos}

A metodologia utilizada abrangeu a investigação científica que depende de um conjunto de procedimentos intelectuais e técnicos para que seus objetivos sejam atingidos: os métodos científicos. Segundo Andrade (2001, p. 128), "metodologia é o conjunto de métodos ou caminhos que são percorridos na busca do conhecimento".

Foi feita uma pesquisa pura ou básica que visa a melhorar o conhecimento com o desenvolvimento de metodologias, melhores diagnósticos e estudos mais aprofundados dos fenômenos.

Para a elaboração e concretização desta pesquisa foi necessário realizar um levantamento bibliográfico referente a crimes ambientais e a legislação ambiental desenvolvido com base em material já elaborado, constituído principalmente de livros e artigos científicos, visando a compreender o problema a partir de referências teóricas publicadas.

$\mathrm{O}$ estudo tratou de um levantamento, que basicamente se deu através da solicitação de informações a um grupo significativo de pessoas de determinados órgãos acerca do problema estudado, para, mediante análise qualitativa e quantitativa, obterem-se as conclusões correspondentes aos dados coletados (Gil, 2001), ou seja, foi feita uma coleta de dados junto ao Instituto Brasileiro do Meio Ambiente e dos Recursos Naturais Renováveis (IBAMA) e à Superintendência de Administração do Meio Ambiente (SUDEMA) para analisar quantas infrações ambientais foram cometidas contra o meio ambiente no Estado da Paraíba, no período compreendido entre os anos de 2007 e 2011.
Utilizamos o método dedutivo: também chamado por Aristóteles de silogismo, o raciocínio dedutivo parte da dedução formal tal que, postas duas premissas, delas, por inferência, se tira uma terceira, chamada conclusão. A dedução organiza e especifica o conhecimento que já se tem, mas não é geradora de conhecimentos novos. Ela parte do geral para o particular, indo do todo para as partes, e o método histórico que consiste em investigar acontecimentos, processos e instituições do passado para verificar sua influência na sociedade de hoje. Pesquisar como evoluiu, como foi implantado determinado processo, instituição, etc. Lakatos e Marconi (2001). O que justificou a realização do presente trabalho foi perceber que a cada dia a natureza clama por socorro, mas continua sendo destruída de forma drástica e irreversível.

\section{Resultados e discussão}

\section{Considerações gerais sobre a questão ambiental}

Para efeitos jurídicos, o art. $3^{\circ}$, inciso I, da Lei $\mathrm{n}^{\mathrm{o}}$ 6.938/1981 (Lei da Política Nacional do Meio Ambiente), conceitua o meio ambiente como "o conjunto de condições, leis, influência e interações de ordem física, química e biológica, que permite, abriga e rege a vida em todas as suas formas". Atualmente enquanto bem jurídico tutelado constitucionalmente o meio ambiente pode ser classificado da seguinte maneira:

a) Meio ambiente natural ou físico pode ser considerado como constituído pelo solo, pela água, pelo ar, pela fauna e pela flora, ou seja, pelos elementos físicos, químicos e biológicos que compõem a natureza e os seres vivos.

b) Meio ambiente artificial - que este se refere ao espaço físico transformado pelo ser humano para se adequar as suas necessidades. Compreendem edificações, ruas, avenidas, praças etc.

c) Meio ambiente cultural - é aquele composto por bens e valores aos quais a comunidade atribui relevância em função de sua identidade e formação.

d) O meio ambiente do trabalho pode ser visto como aquele que faz a relação entre as patologias apresentadas 
pelos trabalhadores e sua relação com as atividades por eles desenvolvidas.

O Direito Ambiental é um ramo do Direito que estuda as relações jurídicas ambientais, observando a natureza constitucional, difusa e transindividual dos direitos e interesses ambientais, buscando a sua proteção e efetividade (Milaré, 2002).

Segundo o autor supracitado o Direito Ambiental, como o meio ambiente, não possui um conceito preciso acerca de sua definição. Contudo, pode-se afirmar que o Direito Ambiental trabalha as normas jurídicas dos vários ramos do direito, bem como se relaciona com outras áreas do saber humano como a biologia, a física, a engenharia, o serviço social, etc. É, portanto o Direito Ambiental uma matéria multidisciplinar que busca adequar $\mathrm{o}$ comportamento humano com o meio ambiente que o rodeia. Outra importante constatação é o fato de ser um direito difuso, ou seja, pertence a todos os cidadãos e não a uma ou outra pessoa ou conjunto de pessoas determinadas.

Tepedino (1999) comenta:

[...] mais do que um novo ramo do direito, o direito ambiental representa, com efeito, uma ruptura com 0 instrumental teórico e processual do passado, chegando a alterar até mesmo o papel desempenhado pelos profissionais do direito e, em particular, pelo magistrado. (Tepedino, 1999, p. 294).

Sem dúvida que a sobrevivência da espécie humana e sua qualidade de vida dependem de um meio ambiente ecologicamente equilibrado.

Para Teixeira (2000), “a degradação ambiental coloca em risco direto a vida e a saúde das pessoas, individual e coletivamente consideradas, bem como a própria perpetuação da espécie humana.”

O Brasil é conhecido internacionalmente pela quantidade e, principalmente, pela qualidade das normas existentes em matéria ambiental. No entanto, ao longo das últimas duas décadas tem se verificado que muitas dessas normas não se prestam ao objetivo pelas quais foram criadas, uma vez que os problemas que elas visam a combater estão cada vez mais presentes.
Benjamin (2004), um dos precursores do Direito Ambiental no Brasil, ao ser indagado sobre a efetividade das leis ambientais no Brasil, assim respondeu: "Essa efetividade ainda é vaga. A lei é boa, mas sua aplicação é ruim”. Precisamos criar mecanismos que propiciem uma boa aplicação da lei e o fortalecimento das instituições que têm responsabilidade, para que de fato o meio ambiente comece a ter algum direito.

Neste século a destruição do meio ambiente constitui um dos maiores problemas que a humanidade tem enfrentado cuja gravidade é amplamente conhecida, pelo que representa para a vida e para a própria sobrevivência do ser humano (Foladori, 2001). Nestes últimos anos, poucas questões levantaram tamanha e heterogênea preocupação, o que conduziu a uma disseminação da luta do patrimônio ecológico comum (Prado, 2005).

O ser humano inicia este novo período cheio de incertezas no que se refere à questão ambiental, em conseqüência de uma ideologia de progresso a qualquer custo, a qual subordinou o meio ambiente ao crescimento econômico. Todo o conhecimento científico, contido nas Geociências, nas Biociências e nas Ciências Humanas, fala da fragilidade do meio natural e da agressividade do ser humano (Milaré, 2009).

\section{Para Milaré(2009):}

A problemática ambiental está na ordem do dia. Basta atentar para as fontes de informação para ver que as agressões ao ambiente desfilam diuturnamente nos noticiários, nem sempre sensibilizando a sociedade e os seus dirigentes. Tudo decorre de um fenômeno correntio, segundo o qual os homens, para satisfação de suas novas e múltiplas necessidades, que são ilimitadas, disputam os bens da natureza, por definição limitados. E é esse fenômeno, tão simples quanto importante e pouco avaliado, que está na raiz de grande parte dos conflitos que se estabelecem no seio das comunidades locais e da sociedade em geral.

De outro lado, o processo de desenvolvimento dos países se realiza, basicamente, à custa dos recursos naturais vitais, provocando a 
deterioração das condições ambientais em ritmo e escala até ontem ainda desconhecidos. A paisagem natural da Terra está cada vez mais ameaçada pelos riscos nucleares, pelo lixo atômico, pelos dejetos orgânicos, pela “chuva ácida”, pelas indústrias e pelo lixo químico. Por conta disso, em todo o mundo - e o Brasil não é nenhuma exceção - o lençol freático se abaixa e se contamina, a água se escasseia a área florestal diminui, o clima sofre profundas e quiçá irreversíveis alterações, o ar se torna irrespirável, o patrimônio genético se degrada, abreviando os anos que o homem tem para viver sobre o planeta. Isto é, do ponto de vista ambiental o planeta chegou quase ao ponto de não retorno. Se fosse uma empresa estaria à beira da falência, pois dilapida seu capital, que são os recursos naturais, como se eles fossem eternos. $\mathrm{O}$ poder de autopurificação do meio ambiente está chegando ao limite.

Não há dúvida, pois, que questão ambiental, por esse prisma, é uma questão de vida ou morte, não apenas de animais e plantas, mas do próprio homem e do planeta que o abriga, pois a Terra também é considerada um organismo vivo sui generis. (Milaré, 2009, p. 58-59).

Em nada diferindo de outras nações do mundo, o Brasil alavancou o progresso apoiado em modelos econômicos nos quais para crescer era preciso destruir. Assim, o desenvolvimento industrial, o progresso tecnológico, a urbanização desenfreada, a explosão demográfica, a falta de água potável que mata uma criança a cada 19 segundos no mundo (PNUD, 2006), entre outros fatores, têm tornado atual e dramático o problema da limitação dos recursos do nosso planeta e da degradação da Natureza (Prado, 2005).

\section{Histórico do Direito Ambiental no Brasil \\ Comecemos pela época do} descobrimento do Brasil, período em que a lei em vigor era as Ordenações Afonsinas, publicadas em 1446, durante o reinado de D. Afonso V, esta era formada por uma espécie de coletânea ou código de leis baseada no Direito Romano, no Direito Canônico e outras fontes jurídicas e que reunia toda a legislação em vigor a altura.
Esta lei já trazia uma espécie de direito ambiental, quando tipificava o corte de arvores de fruto como crime de injuria ao rei.

Após esse período passou a vigorar as Ordenações Manuelinas em 1521, esta lei já era um pouco mais avançada em relação à matéria do meio ambiente, pois proibia a caça de certos animais, coibia a comercialização de colméia sem a preservação da vida das abelhas e manteve como crime o corte de arvores frutíferas, mandando o infrator para o Brasil quando a arvore cortada tivesse valor superior a "trinta cruzados", moeda utilizada na época.

Em seguida tivemos como lei a Ordenação Filipinas à mesma proibia qualquer pessoa de jogar material que pudesse matar os peixes ou sujar as águas dos rios e lagoas, mantinha ainda como crime o corte de arvores frutíferas e proibia a pesca com determinados instrumentos e em locais e períodos determinados.

Milaré (2009) ensina-nos que:

Nossa história, infelizmente, é de depredação ambiental impune. $\mathrm{Na}$ prática, somente eram punidos os delitos que atingissem a Coroa ou os interesses fundiários das classes dominantes. O patrimônio ambiental coletivo, como o conhecemos hoje, era inimaginável. Não por falta de doutrina que se encontrava alhures, mas por força do estreito e fechado círculo dos interesses familiares, feudais ou oligárquicos. (Milaré, 2009, p. 783).

Esta observação está relacionada com a visão que os colonizadores tinham do Brasil, que não passava de uma fonte inesgotável de recursos naturais.

\section{A questão ambiental nas constituições brasileiras}

Milaré (2005) descreve que antes da promulgação da Constituição brasileira de 1988, as constituições anteriores não haviam ainda dispensado, à proteção ambiental, a necessária relevância.

A Constituição de 1824, em seu art. $179, n^{\circ} 24$, proibia a instalação de indústrias contrárias à saúde do cidadão, o que aparenta ser um avanço para a época.

Já a Constituição de 1891, no art. 34, $\mathrm{n}^{\circ} 09$ previa que a competência 
legislativa para legislar sobre minas e terras era da União.

Enquanto a Constituição de 1934 dispôs ligeira preocupação em tutelar o patrimônio cultural, histórico e paisagístico do País, e atribuiu competência legislativa para a União em matéria de riquezas do subsolo, mineração, águas, floresta, caça, pesca e a sua exploração.

A preocupação da Carta Constitucional de 1937 foi em relação aos monumentos históricos, artísticos e naturais. E atribuía competência para União legislar sobre minas, águas, florestas, caça, pesca, subsolo e proteção das plantas e rebanhos.

As Constituições de 1946 e 1967 mantiveram a mesma estrutura da Constituição de 1934, em relação aos temas abordados.

A Emenda Constitucional de 1969 manteve as mesmas disposições da Constituição emendada, no que pertence à matéria. Porém, o que podemos considerar como uma inovação foi a introdução do vocábulo “ecológico” no texto legal.

Medeiros (2004) afirma que:

De qualquer sorte, apesar de não possuírem uma visão holística do ambiente e nem uma conscientização de preservacionismo, por intermédio de um desenvolvimento técnico-industrial sustentável, essa Cartas tiveram o mérito de ampliar, de forma significativa, as regulamentações referentes ao subsolo, à mineração, à flora, à fauna, às águas, dentre outros itens de igual relevância. (Medeiros, 2004, p. 62).

Silva (2004) descreve que, a partir da constituição de 1946, "apenas se extraía orientação protecionista do preceito sobre a proteção da saúde e sobre a competência da União para legislar sobre água, florestas, caça e pesca.”

Em 1988 a crescente preocupação do Brasil em relação à questão ambiental fez com que finalmente o meio ambiente recebe-se sua necessária relevância com a promulgação da Constituição Brasileira de 1988, denominada, por muitos, como Constituição Verde ou Ambientalista por inserir em seu texto o tema meio ambiente, destacando em seu Capítulo VI, do Título VIII, “Da Ordem Social”, exclusivamente o meio ambiente, o qual, em seu único artigo o 225, garante a todos o direito ao meio ambiente ecologicamente equilibrado. Outros dispositivos inseridos ao longo de todo Texto Constitucional disciplinam a matéria meio ambiente.

Desta forma podemos salientar que a Constituição de 1988 foi, portanto, a primeira a tratar deliberadamente da questão ambiental. Pode-se dizer que ela é uma Constituição eminentemente ambientalista.

Esta carta estabeleceu que o meio ambiente é um bem de uso comum do povo, assegurando a todos o direito ao meio ambiente equilibrado, impondo ao Poder Público e à coletividade o dever de defendê-lo e preservá-lo à presente e às futuras gerações e ampliou as ações judiciais na tutela ambiental.

Silva (2004) ponderou a respeito do que está expresso na atual carta magna:

As normas constitucionais assumiram a consciência de que o direito à vida, como matriz de todos os demais direitos fundamentais do homem é que há de orientar toda a forma de atuação no campo da tutela do meio ambiente. Compreendeu que ele é um valor preponderante que há de estar acima de quaisquer considerações como as de desenvolvimento, como as de respeito ao direito de propriedade, como as da iniciativa privada. Também são garantidos no texto constitucional, mas, a toda evidência, não podem primar sobre o direito fundamental à vida que está em jogo quando se discute a tutela da qualidade do meio ambiente, que é instrumental no sentido de que, através desta tutela, o que se protege é um valor maior: a qualidade da vida humana. (Silva, 2004, p. 818).

Estes preceitos constitucionais impuseram aos legisladores a responsabilidade de proporem leis cada vez mais severas, e aos juízes a árdua missão de aplicar punições também severas, para que esses preceitos constitucionais sejam realmente aplicados. 

ambiental

\section{As normas penais de proteção}

A legislação ambiental brasileira é considerada uma das mais completas do mundo e além de tudo muito vasta, composta por numerosas leis, algumas recentes, outras já existem há tempos. Como exemplos podemos citar:

O Decreto $\mathrm{n}^{\circ} \quad 16.300 / 1923$

(Regulamento da Saúde Pública); o Decreto $\mathrm{n}^{\circ}$ 23.793/1934 (Código Florestal), depois substituído pela Lei $\mathrm{n}^{\circ}$ 4.77l/1965; o Decreto $n^{\circ}$ 24.114/1934 (Regulamento de Defesa Sanitária Vegetal); o Decreto $\mathrm{n}^{\mathrm{o}}$ 24.643/1934 (Código de Águas); o DecretoLei $n^{\circ}$ 25/1934 (Patrimônio Cultural), que organiza a proteção do patrimônio histórico e artístico nacional; o Decreto-Lei $\mathrm{n}^{\mathrm{o}}$ 794/1938 (Código de Pesca), depois substituído pelo Decreto-Lei n ${ }^{\circ}$ 221/1967; o Decreto-Lei no 2.848/1940 (Código Penal); Lei ${ }^{\circ}$ 4.504/1964 (Estatuto da Terra); a Lei $\mathrm{n}^{\circ}$ 4.771/1965 (Código Florestal); a Lei $\mathrm{n}^{\circ}$ 5.197/1967 (Proteção à Fauna); o DecretoLei $n^{\circ}$ 221/1967 (Código de Pesca); o Decreto-Lei $n^{\circ}$ 248/1967 (Política Nacional de Saneamento Básico); o Decreto-Lei $\mathrm{n}^{\circ}$ 303/1967 (Criação do Conselho Nacional de Controle da Poluição Ambiental); a Lei $\mathrm{n}^{\circ}$ 5.138/1967 (Política Nacional de Saneamento, que revogou o Decreto-Lei $\mathrm{n}^{\circ}$ 248/67 e o Decreto-Lei $n^{\circ}$ 303/1967); a Lei $\mathrm{n}^{\circ} 5.357 / 1967$ (estabelece penalidades para embarcações e terminais marítimos ou fluviais que lançarem detritos ou óleo em águas brasileiras); o Decreto-Lei $\mathrm{n}^{\mathrm{o}}$ 1.413/1975 (Controle da Poluição do Meio Ambiente Provocada por Atividades Industriais); a Lei $\mathrm{n}^{\circ} \quad 6.453 / 1977$ (Responsabilidade Civil por Danos Nucleares e Responsabilidade Criminal por Atos Relacionados com Atividades Nucleares); a Lei no 6.523/1977 (Criação de Áreas Especiais e Locais de Interesse Turístico); a Lei $\mathrm{n}^{\circ} \quad 6.766 / 1978$ (Parcelamento do Solo Urbano), e muitas outras.

Dentro da grande vastidão de leis sobre itens ambientais, Machado (2006) cita e descreve 17 delas, que são as mais importantes, e podem garantir a preservação do grande patrimônio ambiental do país.
Com todos estes exemplos sem sombra de dúvidas podemos perceber que o meio ambiente interessa ao Direito Penal, sendo objeto de sua proteção, mediante a previsão de crimes ambientais e da cominação das penas que lhes são cabíveis, e por essa razão as previsões de crime ambiental na legislação pátria há muito ocorrem, porém se verificavam de forma desordenada e irregular.

Pela pluralidade de leis, era muito mais difícil a tarefa do intérprete de enquadrar penalmente os infratores ambientais, o que, por outro lado, facilitava a ação danosa, pelo caráter disperso que assumia o aparato legal de proteção ao meio ambiente.

Este cenário jurídico precisava de uma reorganização do aparato legal de proteção penal ao meio ambiente. Essa necessidade ocorria tanto do ponto de vista estrutural, onde o ideal seria um diploma legal único; quanto sob aspecto de conteúdo, que deveria ser reavaliado.

Finalmente, no ano de 1998, surge a mais importante delas, a Lei $\mathrm{n}^{\circ}$ 9.605/1998, que trata dos crimes ambientais (Brasil, 1988).

\section{Ambientais}

\section{Lei $n^{0}$ 9.605/1998 - Lei de Crimes}

A sanção presidencial da Lei $n^{\circ}$ 9.605/1998 ou a Lei dos Crimes Ambientais (Brasil, 1998), composta por 82 artigos distribuídos em oito capítulos, representa um marco importante no Direito Penal brasileiro, garantindo à sociedade, aos órgãos ambientais e ao Ministério Público a agilidade e a eficácia para punir as pessoas físicas ou jurídicas que cometerem qualquer infração contra o meio ambiente.

Entretanto, esta Lei não trata apenas de punições, ela incluiu formas e possibilidades da não aplicação de penas, desde que o infrator recupere o dano, ou pague sua dívida à sociedade para compensar o dano causado.

De conteúdo abrangente, descreve muitas infrações penais ambientais, dispõe ainda sobre infrações administrativas, responsabilidade civil, normas de processo penal e requisitos para cooperação internacional. 
Ela classifica os crimes ambientais em seis tipos diferentes:

1- Crimes contra a fauna;

2- Crimes contra a flora;

3- Poluição e outros crimes ambientais;

4- Crimes contra o ordenamento urbano e o patrimônio cultural; ambiental; e

5- Crimes contra a administração

6- Infrações administrativas.

Esta Lei $\mathrm{n}^{\circ}$ 9.605/1998 introduziu inovações relevantes em termos de proteção ao meio ambiente.

O Brasil, com a entrada em vigor da Lei $n^{\circ}$ 9.605/1998, deu um grande passo em relação à proteção do meio ambiente, pois a nova legislação trouxe inovações modernas para repreender a destruição ambiental, estas estão descritas por Araújo (1998) na cartilha do IBAMA, denominada a Lei da Natureza, fazendo um comparativo da legislação ambiental antes e depois de sua entrada em vigor.

Dentre tantas inovações, desgarrando-se da doutrina clássica penal, o legislador brasileiro passou a responsabilizar penalmente a pessoa jurídica por crimes ambientais, tornando esta atitude um dos aspectos mais modernos da referida lei, tratada no art. $3^{\circ}$, que descreve:

Art. $3^{\circ}$ As pessoas jurídicas serão responsabilizadas administrativa, civil e penalmente conforme o disposto nesta Lei, nos casos em que a infração seja cometida por decisão de seu representante legal ou contratual, ou de seu órgão colegiado, no interesse ou benefício da sua entidade. (Brasil, 1998).

Para que seja possível a responsabilização penal da pessoa jurídica, Santos (2002), explica que:

Logo, dois são os requisitos para que uma pessoa jurídica seja penalmente responsável: $1^{\circ}$ ) o ato lesivo ao meio ambiente tenha decorrido de uma decisão (do representante legal, contratual ou do órgão colegiado); $2^{\circ}$ ) o ato tenha sido praticado no interesse ou benefício da pessoa jurídica. (Santos, 2002, p. 49).

Ao serem preenchidos tais requisitos, qualquer pessoa jurídica, ou seja, somente aquelas consideradas pela lei como tal, poderão ser sujeitos ativos de crimes ambientais, daí o próprio Estado pode ser incluído, vez que a lei considera pessoa jurídica os entes da administração direta e indireta, nas três esferas (união, estados/distrito federal e municípios).

Outro importante elemento descrito no parágrafo único, do art. $3^{\circ}$, da Lei $\mathrm{n}^{\circ}$ 9.605/1998, é que, a responsabilidade penal da pessoa jurídica, não exclui a da pessoa física co-relacionada. Assim dispõe Santos (2002):

De outra parte, as pessoas físicas não escapam a responsabilidade penal que eventualmente poderia lhes caber, de acordo com o art. $3^{\circ}$, parágrafo único da Lei $\mathrm{n}^{\circ}$ 9.605/98, havendo possibilidade de cumular-se as responsabilidades emergentes dos membros dela, na qualidade de autores ou partícipes. Cumpre ressaltar que foi adotado o sistema da dupla imputação, ou seja, não se tratam de responsabilidades excludentes, mas, como foi salientado, cumulativas. (grifo do autor) (Santos, 2002, p. 49).

Devemos esclarecer que a doutrina penal do nosso país não é unânime quando trata sobre a responsabilidade penal da pessoa jurídica, porém, o constituinte de 1988, no art. 225, § $3^{\circ}$, da Constituição Federal, deixou clara a sua intenção de envolver as pessoas morais ou jurídicas, no que diz respeito à responsabilidade ambiental, inclusive aquela de cunho penal. Seguindo este raciocínio, Bonfim e Capez (2004) afirmam que:

Ora, se foi vontade do constituinte e do legislador proteger bens jurídicos relevantes, tais como o meio ambiente e a ordem econômica, contra agressões praticadas por entidades coletivas, não há como negar tal possibilidade ante argumentos de cunho individualista, que serviam de fundamento para a Revolução Burguesa de 1789. A sociedade moderna precisa criar mecanismos de defesa contra agressões diferentes que surgem e se multiplicam 
dia a dia. Assim é o finalismo, o funcionalismo e outras teorias do direito penal que devem adaptar-se à superior vontade constitucional, não o contrário. Nesse passo, a Lei $\mathrm{n}^{\circ}$ 9.605/1998, apenas atendeu ao comando constitucional, e, dessa forma, em seu artigo $3^{\circ}$ dispôs expressamente que as pessoas jurídicas serão responsabilizadas penalmente nos casos em que a infração seja cometida por decisão de seu representante legal ou de seu órgão colegiado, não deixando, portanto, qualquer dúvida quanto à possibilidade de responsabilização criminal de empresas que pratiquem crimes contra o meio ambiente. (Bonfim e Capez, 2004, p. 297).

Desta maneira podemos deduzir que a pessoa jurídica pode e deve ser responsabilizada pelos crimes ambientais que vier a cometer, com base na Constituição Federal de 1988, e na forma da lei, podendo ainda ocorrer com a mesma a desconsideração da sua personalidade, sempre que a personalidade jurídica for utilizada como anteparo de fraude e abuso de direito quando em detrimento da qualidade do meio ambiente, devendo ser decretada sua liquidação forçada, seu patrimônio será considerado instrumento do crime e como tal perdido em favor do Fundo Penitenciário Nacional.

Sobre o tema, Milaré (2005) ensina que as entidades jurídicas continuam a ser distintas e separadas de seus membros, mas tal distinção e separação podem ser desconsideradas sempre que a personalidade jurídica for utilizada como anteparo da fraude e abuso de direito.

Embora a intenção do legislador em sede de proteção ao meio ambiente seja a toda evidência louvável, com tantas inovações, a Lei n ${ }^{\circ}$ 9.605/1998, como tantas outras, possui suas falhas e deixa implícito que poderia ter sido mais bem trabalhada quando de sua elaboração, a fim de cumprir ao que se destina. Pertinente é a crítica de Machado (1998, p. 587) nesse sentido:

As contravenções penais relativas à proteção da flora em sua maioria foram transformadas em crimes. Contudo, áreas como a Amazônia, o Pantanal e a Mata Atlântica deveriam ter sido protegidas penalmente de forma mais eficiente. Não acreditamos que os novos crimes e o sistema penal a ser aplicado serão suficientes e eficazes para disciplinar os grupos nacionais e estrangeiros em atividade nessas áreas. (Machado, 1998, p. 587).

Infelizmente, a legislação penal ambiental no Brasil apesar de ser uma das mais complexas do mundo, pelo que percebemos tem apenas uma função simbólica, pois o processo de destruição do meio ambiente em suas varias espécies continua de forma acelerada e descontrolada sem que o homem perceba o que esta fazendo para sua própria destruição.

\section{Aplicação prática da Lei $\mathbf{n}^{0}$ 9.605/1998 no Estado da Paraíba}

Como podemos observar na Figura 1 , no período compreendido entre os anos de 2007 e 2011, de um total de 4.957 autos de infração aplicados no Estado da Paraíba, a SUDEMA aplicou 1.944, perfazendo um percentual de 39,22\%, enquanto o IBAMA aplicou 3.013 autos de infração, perfazendo um percentual de $60,78 \%$.Com exceção do ano de 2007, onde o IBAMA aplicou 604 autos de infração e a SUDEMA aplicou 792, o órgão federal foi bem mais eficiente na aplicação das multas.

É interessante notar que, embora os órgãos de fiscalização do meio ambiente sejam sempre atuantes na fiscalização e eficazes na aplicação de multas, onde as ações são sempre veiculadas nos meios de divulgação de massa, os números de autos de infração são sempre numerosos.

O que esperávamos encontrar neste estudo era um número decrescente de autos de infração, provocado pela divulgação das ações dos órgãos de fiscalização e pela aplicação das multas cada vez mais elevadas. Entretanto, o que observamos na análise dos dados obtidos no IBAMA e na SUDEMA foi aplicação de um número considerável de autos de infração. Com exceção do ano de 2010, onde foram aplicadas 655 autos de infração, nos demais períodos pesquisados, foram aplicados em média 1.075 autos de infração por ano.

O número elevado de autos de infração aplicados pelos órgãos de fiscaliza- 
Figura 1. Multas aplicadas no Estado da Paraíba pelo IBAMA e SUDEMA, no período de 2007 a 2011.

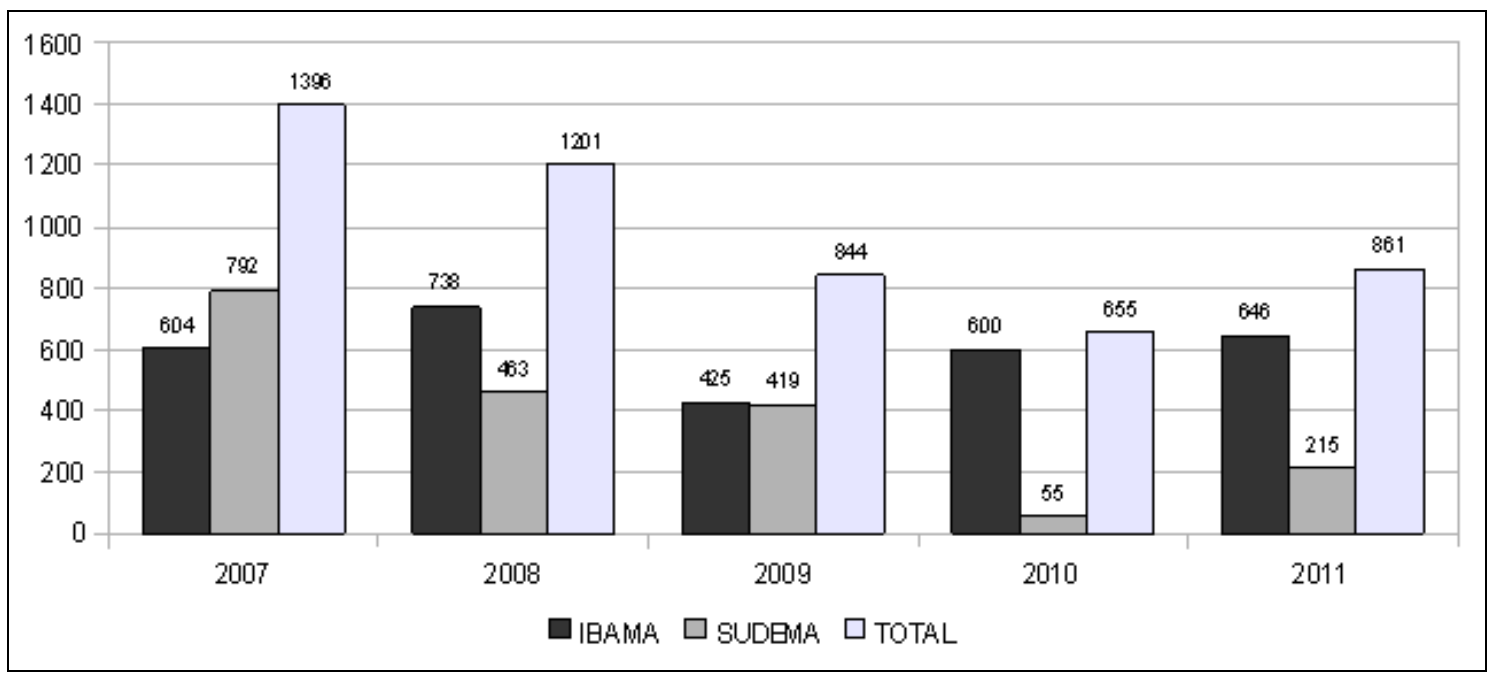

Fonte: IBAMA e SUDEMA.

ção do meio ambiente no Estado da Paraíba demonstra, entre outras coisas, que a aplicação da Lei dos Crimes Ambientais (Lei ${ }^{\circ}$ 9.605/1988) ainda é pouco eficaz.

A ineficiência da aplicação da Lei dos Crimes Ambientais não está relacionada aos seus mecanismos, considerando serem esses bastante eficientes, tendo em vista que o art. 72 da referida lei discrimina que as infrações administrativas ao meio ambiente são punidas com as seguintes sanções: advertência; multa simples; multa diária; apreensão dos animais, produtos e subprodutos da fauna e flora, instrumentos, petrechos, equipamentos ou veículos de qualquer natureza utilizados na infração; destruição ou inutilização do produto; suspensão de venda e fabricação do produto; embargo de obra ou atividade; demolição de obra; suspensão parcial ou total de atividades; bem como sanções restritivas de direitos (prestação de serviços à comunidade; interdição temporária de direitos; suspensão parcial ou total de atividades; prestação pecuniária; e recolhimento domiciliar).

De fato, nos últimos anos, temos visto, através das notícias veiculadas nos portais da Internet (vide Camargo, 2011; Quaino, 2011), que os valores das multas aplicadas pelo IBAMA são cada vez mais elevados, com o intuito de persuadir os infratores, através de sua descapitalização, a não mais cometerem este tipo de infração.
Do cometimento da infração ambiental advém o processo administrativo, onde é cobrado o pagamento da multa e verificado a necessidade de recuperar a área afetada pelo dano ambiental. Cada um dos processos administrativos é encaminhado ao Ministério Público Estadual, para ser aberto processo penal, considerando que a maioria das infrações ambientais são consideradas infrações penais.

O Ministério Público Federal (MPF), o Ministério Público Estadual (MPE) e a Advocacia Geral da União (AGU), podem ingressar ainda, conjuntamente ou sozinhos, com Ação Civil Pública (ACP) para que o infrator seja obrigado a recuperar o meio ambiente do dano ambiental cometido, exigindo-se, inclusive, compensação financeira, pelo cometimento da infração.

Caso a multa não seja paga após 75 dias do julgamento do auto de infração, o débito é inscrito no Cadastro de Inadimplentes do Governo Federal (CADIN) e encaminhado à AGU, que pode ingressar com processo de execução fiscal, para obrigar o pagamento do débito.

Como o processo de execução fiscal de cobrança de débitos oriundos de multas relacionadas à infração ambiental é muito demorado, e muitas vezes são atingidos pela prescrição, há a falsa impressão de que os órgãos de fiscalização ambiental são ineficientes no que diz 
respeito à aplicação de multas. Na realidade, a ineficiência recai sobre o modo como estão sendo realizadas as cobranças desses autos de infração.

Outro fator importante para a incidência de grande número de infração à Lei dos Crimes Ambientais e as consequentes autuações reside no modo como esses crimes são tratados no âmbito do judiciário, que, na maioria das vezes, considera o delito ambiental de menor potencial ofensivo, aplicando-se o princípio da insignificância, utilizando os parâmetros contidos na Lei $\mathrm{n}^{\circ}$ 9.099/1995 (Brasil, 1995).

De acordo com Corrêa (2002), há casos em que não obstante as condutas sejam tipificadas como crime, não são dotadas de nenhuma relevância social, podendo-se o princípio da insignificância (bagatela) ser aplicado, onde, devido à irrelevância do dano ao bem jurídico tutelado, o Estado renuncia ao jus puniendi.

Ainda de acordo com Corrêa (2002):

Para que se aplique o princípio da insignificância de maneira justa, é mister que não se confunda conduta irrelevante com conduta de menor potencial ofensivo. Neste o indivíduo praticou uma conduta descrita no verbo-tipo (tipicidade formal) e o juiz deve impor a pena. Sendo porém, o delito de menor potencial ofensivo, deve-se buscar alternativas diversas a pena privativa de liberdade (substituição por restritivas de direito, sursis processual - no caso da Lei $n^{0}$ 9099/1995).

$\begin{array}{cccr}\text { Embora } & \text { o } & \text { princípio } & \text { da } \\ \text { insignificância } & \text { ainda } & \text { não } & \text { esteja }\end{array}$ fundamentado no direito positivo brasileiro, vem consolidando-se como forte instituto da nova política criminal (Corrêa, 2002). De acordo com Capez (2009), há julgado da Suprema Corte no sentido de que, em matéria ambiental, surgindo a insignificância do ato em razão do bem protegido, impõe-se a absolvição do acusado (STF, Tribunal Pleno, AP 439/SP, Rel. Min. Marco Aurélio, j. 12/06/2008). De forma contrária, já se decidiu que "a preservação ambiental deve ser feita de forma preventiva e repressiva, em benefício de próximas gerações, sendo intolerável a prática reiterada de pequenas ações contra 0 meio ambiente, que, se consentida, pode resultar na sua inteira destruição e em danos irreversíveis" (TRF, $1^{\text {a }}$ Região, ACR 2003.34.00.019634-0/DF, Terceira Turma, Re. Des. Olindo Menezes, j. Em 14.02.2006).

Embora para Souza (2011) "as multas, os autos de infração e as acusações penais acerca dos crimes contra o meio ambiente fogem à regra legal, quando são abusivas ou desproporcionais à pessoa fiscalizada”, a certeza da impunidade favorece o cometimento dos crimes ambientais, considerando que aumentará a falsa impressão de que esses delitos têm pouca importância para o judiciário.

De fato, os repetidos insucessos nas cobranças das multas aplicadas pelos órgãos de fiscalização ambiental, que muitas vezes são alcançadas pela prescrição, ou tem valor menor de $\mathrm{R} \$$ 1.000,00 (hum mil reais), que não justifica a abertura de ação de execução fiscal, bem como a aplicação do princípio da insignificância pelo juiz nos crimes ambientais, tem aumentado a sensação de impunidade, provocando um aumento elevado nos números de autos de infração aplicados pelo IBAMA e pela SUDEMA.

\section{Conclusão}

Como podemos observar da fundamentação teórica do presente trabalho, o meio ambiente brasileiro é um dos bens melhores tutelados, que possui um robusto arcabouço de normais de proteção legais, inclusive alçado como direito constitucional na Carta Magna de 1988.

Embora o meio ambiente possua relevante importância no Direito Brasileiro, as infrações à Lei dos Crimes Ambientais (Lei $n^{\circ}$ 9.605/1998) são cada vez mais frequentes e numerosas, a despeito dos órgãos de fiscalização do meio ambiente no Estado da Paraíba, a SUDEMA e o IBAMA, integrantes do Sistema Nacional de Meio Ambiente (SISNAMA), cumprirem seu papel, realizando suas ações fiscalizatórias. A prova disto é que, no período de 2007 a 2011, foram lavrados por estes órgãos 4.957 autos de infração por desrespeitos às normas ambientais. 
Para que as multas aplicadas cumpram sua função pedagógica e consigam persuadir os infratores a não cometerem novos delitos ambientais e impeçam que outras pessoas tentem infringir a Lei dos Crimes Ambientais (Lei no 9.605/1998), é necessário que a certeza da impunidade no cometimento desses crimes deixe de imperar. Para isto, é necessário que haja um esforço concentrado do Judiciário no sentido de julgar os crimes ambientais com o maior rigor que a legislação impõe e que os processos de execução fiscal de débitos decorrentes de multas ambientais sejam mais ágeis, para que eles não sejam alcançados pela prescrição.

Ora, o direito ao meio ambiente ecologicamente equilibrado quando foi alçado na Constituição Federal de 1988, como um direito universal, é um bem tutelado, que deve estar acima dos interesses individuais, por isto não se pode falar em punições abusivas ou desproporcionais no cometimento de delitos ambientais, tampouco aplicar-se o princípio da insignificância. Afinal, as ações negativas impetradas ao meio ambiente poderão ter repercussões deletérias e irreversíveis, e poderão privar as futuras gerações a usufruir de um determinado recurso ambiental. É isto que o Direito Ambiental quer evitar.

Entretanto, há ações de pouca envergadura, como a que ocorreu a quatro cidadãos que foram denunciados pelo Ministério Público do Estado de Minas Gerais por capturarem quatro minhocuçus, espécie de minhoca utilizada para pesca, em 1999, na propriedade de Fausto Campolina Teixeira, localizada em Paraopeba, deve ser vista com certa cautela pelo judiciário. Bem como noticiou Duarte (1999), o Juiz de Direito de Paraopeba entendeu que, por se tratar de crime contra a fauna, tutelada pela Lei $n^{0} 5.197 / 1967$, a competência para o julgamento da ação seria da Justiça Federal. Assim o Juízo Federal da $4^{\text {a }}$ Vara da Seção Judiciária do Estado de Minas Gerais encaminhou o processo para o Superior Tribunal de Justiça (STJ), alertando para a insignificância do fato a ser apurado. Na proclamação de seu voto, o ministro Fernando Gonçalves, relator do processo, corroborou com a tese do crime de bagatela, considerando que capturar quatro minhocuçus não tem relevância jurídica, uma vez que a conduta dos acusados não tem poder lesivo suficiente para atingir o bem tutelado (a fauna silvestre brasileira), e a pena porventura aplicada seria mais gravosa do que o dano provocado pelo ato delituoso.

No entanto é bom lembrar que as infrações contra as normas ambientais são, de acordo com a Lei $\mathrm{n}^{\circ}$ 9.605/1998, consideradas crimes. Assim, como bem frisou Santos; Sêga (2000), ao estabelecer no art. 61, da Lei $\mathrm{n}^{\circ}$ 9.099/1995 (Brasil, 1995) as infrações penais de menor potencial ofensivo não as considerou crimes de bagatela, porque estes são considerados como "não-crime", assim, fora da competência dos Juizados Especiais e, até mesmo, fora da intervenção do direito penal.

De outro lado, é necessário que os órgãos de fiscalização ambientais adotem medidas eficazes para que as cobranças administrativas das multas imputadas aos infratores sejam mais eficientes, inclusive com a permissão de parcelamento, cada vez mais generosos, e que as negociações dos valores das multas impostas contemplem descontos nos pagamentos antecipados.

Diante de tudo o que foi aqui apresentado podemos concluir que, apesar da Lei dos Crimes Ambientais (Lei $n^{\circ}$ 9.605/1998) ter punições severas para as infrações cometidas contra o meio ambiente, o número de autos de infração, lavrados na SUDEMA e IBAMA no período de 2007 e 2011, foram numerosos, devido a falsa impressão de impunidade, provocada pela ineficiência do Estado em cobrar as multas aplicadas e do judiciário considerar estas infrações penais como de menor potencial ofensivo.

Por fim, também podemos, apesar de termos uma das legislações ambientais mais completas do mundo, percebemos a sua ineficácia diante de tudo que esta ocorrendo com o nosso planeta e principalmente no nosso país.

\section{Declaração de conflito de interesses}

Os autores declaram não haver conflitos de interesses. 


\section{Referências}

Aceti Júnior, L. C. O Brasil precisa de um instituto de direito ambiental. Disponível em: $<$ http://www.redeambiente.org.br/Opiniao.asp?a rtigo $=62>$. Acesso em: 31 ago. 2011.

Andrade, M. M. Introdução à metodologia do trabalho científico: elaboração de trabalhos na graduação. 5. ed. São Paulo: Atlas, 2001.

Araújo, U. A Lei da Natureza. 1998. Disponível em <http://mundoverdeoverfixambiental.blogspot.com.br/2011/02/leida-natureza-ubiracy-araujo.html>. Acesso em: 21 set. 2014.

Art, H. W. Dicionário de Ecologia e Ciências Ambientais. São Paulo: Melhoramentos, 1998.

Ávila, H. Teoria dos princípios - Da definição à aplicação dos princípios jurídicos. 5. ed. São Paulo: Malheiros Editores, 2006.

Azevedo, P. F. Do Direito Ambiental Reflexões sobre seu sentido e aplicação. Revista de Direito Ambiental, São Paulo, v. 19, 2000.

Benjamin, A. H. Temos uma das mais completas leis ambientais do mundo. Mas a aplicação não é plena. Jornal da ABRAMPA, Belo Horizonte, ano 1, jul. 2004.

Bianchini, A. Pressupostos materiais mínimos da tutela penal. São Paulo: Editora Revista dos Tribunais, 2003.

Bitencourt, C. R. Tratado de Direito Penal parte geral 1. 10 ed. São Paulo: Saraiva, 2006.

Bonfim, E. M.; Capez, F. Direito Penal: parte geral. São Paulo: Saraiva, 2004.

Brasil. Leis, decretos, etc. Constituição da República Federativa do Brasil de 1988. Brasília: Senado, 1988. Disponível em: $<$ http://www.planalto.gov.br/ccivil_03/constitui cao/constituiçao.htm>. Acesso em: 28 ago. 2014.

Brasil. Leis, decretos, etc. Lei $\mathbf{n}^{0}$ 9.099, de 26 de setembro de 1995. Dispõe sobre os Juizados Especiais Cíveis e Criminais e dá outras providências. Disponível em: $<$ http://www.planalto.gov.br/ccivil_03/leis/L960 5.htm>. Acesso em: 28 ago. 2014.

Brasil. Leis, decretos, etc. Lei $\mathbf{n}^{0} \mathbf{9 . 6 0 5}$, de 12 de fevereiro de 1998. Dispõe sobre as sanções penais e administrativas derivadas de condutas e atividades lesivas ao meio ambiente, e dá outras providências. Disponível em: <http://www.planalto.gov.br/ccivil_03/leis/L960 5.htm>. Acesso em: 28 ago. 2014.

Brasil. Leis, decretos, etc. Decreto $\mathbf{n}^{\circ}$ 3.179, de 21 de setembro de 1999. Dispõe sobre a especificação das sanções aplicáveis às condutas e atividades lesivas ao meio ambiente, e dá outras providências. Disponível em: <http://www.planalto.gov.br/ccivil_03/decreto/ D3179impressao.htm>. Acesso em: 28 ago. 2014.

Brasil. Leis, Decretos, etc. Decreto $\mathbf{n}^{0}$ 6.514, de 22 de julho de 2008. Dispõe sobre as infrações e sanções administrativas ao meio ambiente, estabelece o processo administrativo federal para apuração destas infrações, e dá outras providências. Disponível em: <http://www.planalto.gov.br/ccivil_03/_Ato200 7-2010/2008/Decreto/D6514.htm>. Acesso em: 28 ago. 2014.

Bugalho, N. R. Crime de Poluição, do artigo 54 da Lei 9.605/98. Revista de Direito Ambiental, 11, ano 3, São Paulo, RT, julho-setembro de 1998.

Camargo, A. Ibama aplica quase meio bilhão de reais em multas. Disponível em: $<$ http://www.hipernoticias.com.br/TNX/conteud o.php?sid=112\&cid=4249>. Acesso em: 29 nov. 2011.

Capez, F. Princípio da insignificância ou bagatela. Jus Navigandi, Teresina, ano 14, n. 2312, 30 out. 2009. Disponível em: $<$ http://jus.com.br/revista/texto/13762>. Acesso em: 29 nov. 2011.

Capez, F. Curso de Direito Penal; parte especial. 7. ed. São Paulo: Saraiva, 2007. v. 2.

Capez, F. Curso de Processo Penal. 15. ed. São Paulo: Saraiva, 2008.

Carrera, F. Vitimologia e meio ambiente - O Planeta Terra em xeque - As infrações ambientais, o dano e o abuso de poder. In: Seguin, E. Vitimologia no Terceiro Milênio. Rio de Janeiro, Forense, 2004.

Corrêa, L. A. A interpretação do princípio da insignificância no Direito Ambiental. Jus Navigandi, ano 7, n. 57, 1 jul. 2002. Disponível em: <http://jus.com.br/revista/texto/2969>. Acesso em: 28 nov. 2011.

Di Pietro, M. S. Z. Direito Administrativo. 15 ed. São Paulo: Atlas, 2003.

Duarte, G. Minhocuçus assoberbam a Justiça. Revista Consulex, Ano III, v. 1, n. 32, p. 11-31, 1999.

Fiorillo, C. A. P. Curso de Direito Ambiental brasileiro. 8. ed. rev., atual. e ampl. São Paulo: Saraiva, 2007.

Foladori, G. Limites do desenvolvimento sustentável. Campinas: Ed. Unicamp, 2001.

Freitas, V. P. A Constituição e a efetividade das normas ambientais. São Paulo: RT, 2000.

Freitas, V. P. Direito administrativo e meio ambiente. 3. ed. Curitiba: Juruá, 2001. 
Gil, A. C. Como elaborar projeto de pesquisa. 4. ed. São Paulo: Atlas, 2001.

Greco, R. Direito Penal do equilíbrio: uma visão minimalista do Direito Penal. Belo Horizonte: UFMG, 2004. (Dissertação de Mestrado).

Hassemer, W. A preservação do ambiente através do Direito Penal. Revista Brasileira de Ciências Criminais, São Paulo, n. 22, 1998.

Jesus, D. E. Direito Penal: parte geral. 20. ed. São Paulo: Saraiva, 1997. v. 1.

Lakatos, E. M.; Marconi, M. A. Metodologia do trabalho científico. 5. ed. São Paulo: Atlas, 2001.

Leal Júnior, C.A.S. O princípio da insignificância nos crimes ambientais: a insignificância da insignificância atípica nos crimes contra o meio ambiente da Lei 9.605/98. Revista de Doutrina da $4^{\text {a }}$ Região, n. 17, 2007. Disponível em: $<$ http://www.revistadoutrina.trf4.jus.br/artigos/e dicao017/Candido_Leal.htm>. Acesso em: 07 abr. 2015.

Lecey, E. Novos direitos e juizados especiais. A proteção do meio ambiente e Juizados Especiais Criminais. Revista de Direito Ambiental, 15, ano 4, São Paulo, 1999.

Littmann-Martin, M. J. A proteção penal do ambiente no direito francês. Revista de Direito Ambiental, 5, ano 2, São Paulo, 1997.

Luz, G. O. A formação de formadores em Educação Ambiental, nos cenários da "Região Metropolitana de Curitiba". Da resistência dos fatos. Curitiba: UFPR, 2001. (Tese de doutorado).

Machado, P. A. L. Direito ambiental brasileiro. 14. ed. rev., atual. e ampl. São Paulo: Malheiros, 2006.

Mazzilli, H. N. A defesa dos interesses difusos em juízo. 17. ed. São Paulo: Saraiva, 2004.

Medeiros, F. L. F. Meio ambiente: Direito e dever fundamental. Porto Alegre: Livraria do Advogado, 2004.

Mendes, P. S. Vale a pena o direito penal do ambiente? 1. reimp. Lisboa: A.A.F.D.L., 2000.

Mezger, E. Tratado de Derecho Penal. In: Prado, L. R.; Bitencourt, C. R. Elementos de Direito Penal: Parte Geral. São Paulo: Revista dos Tribunais, $1995 . \quad$ v. 1. p. 27-28. (Coleção Resumos, 1).

Milaré, E.; Costa Jr., P. J. Direito Penal Ambiental: Comentários à Lei 9.605/98. Campinas: Millennium, 2002.
Milaré, E. Direito do ambiente: doutrina, jurisprudência, glossário. 4. ed. rev. atual. e ampl. São Paulo: Revista dos Tribunais, 2005.

Milaré, E. Direito do ambiente. 6. ed. São Paulo: Revista dos Tribunais, 2009.

Mirabete, J. F. Manual de Direito Penal: Parte Geral - arts. $1^{\circ}$ a 120 do CP. São Paulo: Atlas, 1999.

Moraes, M. E. B. A (in)eficiência do direito penal moderno para a tutela do meio ambiente na sociedade de risco (Lei 9605/98). Rio de Janeiro: Lúmen Júris, 2004.

Quaino, L. Ibama multa Chevron em R\$ 50 milhões por vazamento no Rio. Disponível em: <http:/g1.globo.com/rio-de-janeiro/noticia/ 2011/11/ibama-multa-chevron-em-r-50milhoes-por-vazamento-no-rj-diz-minc.html>. Acesso em: 28 nov. 2011.

PNUD - Programa das Nações Unidas para o Desenvolvimento - Brasil. Relatório do desenvolvimento humano 2006. Disponível em: <http://www.pnud.org.br/arquivos/rdh/ rdh2006/rdh2006.zip>. Acesso em: 28 ago. 2011.

Reale Júnior, M. Meio ambiente e direito penal brasileiro. Revista da Associação Brasileira de Professores de Ciências Penais, v. 2, n. 2, p. 67-83, 2005.

Santos, A. S. R. Meio ambiente do trabalho: considerações. Jus Navigandi, Teresina, ano 4, n. 45, 2000. Disponível em: $<$ http://jus2.uol.com.br/doutrina/texto.asp?id=1 202>. Acesso em: 24 out. 2008.

Santos, C. L. Crimes contra o meio ambiente: responsabilidade e sanção penal. 3 ed. São Paulo: Juarez de Oliveira, 2002.

Santos, M. M.; Sêga, V. A. Sobrevivência do princípio da insignificância diante das disposições da Lei 9099/95. Jus Navigandi, ano 5, n. 46, 1 out. 2000. Disponível em: $<$ http://jus.com.br/revista/texto/950>. Acesso em: 28 nov. 2011.

Silva, J. A. Direito urbanístico brasileiro. São Paulo: Revista dos Tribunais, 1981.

Silva, J. A. Direito ambiental constitucional. 5. ed. São Paulo: Malheiros, 2004.

Souza, D. C. B. Insignificância deve ser verificada em crime ambiental. Revista Consultor Jurídico, 28 de março de 2011. Disponível em: <http://www.conjur.com.br/ 2011-mar-28/principio-insignificancia-aplicadocrimes-ambientais>. Acesso em: 24 out. 2008. 
Teixeira, S. F. O meio ambiente. Revista

Consulex, ano IV, n. 46, 2000.

Tepedino, G. Temas de Direito Civil. Rio de Janeiro: Renovar, 1999.

Informação da Licença: Este é um artigo Open Access distribuído sob os termos da Licença Creative Commons Attribution, que permite uso irrestrito, distribuição e reprodução em qualquer meio, desde que a obra original seja devidamente citada.

Rev. Bras. Gest. Amb. Sustent., 2015, v. 2, n. 3, p.187-201. 